\title{
The inspiration of Bauhaus principles on the modern housing in Cyprus
}

PhD Candidate Mustafa Aziz Amen*

Department of Architecture, Cihan University, Iraq

E mail: mustafaamen@gmail.com

\begin{tabular}{l}
\hline A R T I C L E I N F O: \\
\hline Article history: \\
Received 26 February 2017 \\
Accepted 5 May 2017 \\
Available online 5 May 2017 \\
\hline Keywords: \\
Bauhaus; \\
Modernism; \\
Design principles; \\
Cyprus; \\
Housing layout.
\end{tabular}

This work is licensed under a Creative Commons Attribution NonCommercial - NoDerivs 4.0. "CC-BY-NC-ND"

\begin{abstract}
A B S T R A C T
Modern architecture developed more than a century ago to find solutions suitable to solve the new concerns of the industrial revolution that changed the social idea of the world in all aspects. Bauhaus school which established by Walter Gropius in 1919 adopted too many principles and ideas that were totally new to the architecture concept and theory at that time; their principles started from Simplicity, Angularity, Abstraction, Consistency, Unity, Organization, Economy, Subtlety, Continuity, Regularity, and Sharpness. Those principles affected the architectural world and found its way through many applications in different parts of the world. The unlimited space or the international space that had a significant influence on the architecture space and form as well as the introduction of the new material, the anti-decorating, and Platonic forms had worked to reconstruct the architecture in the world. Cyprus as an Island close to the sources of the movement got the influence from the modern movement. The study will concentrate on Efruz Housing which designed by Ahmet Vural, who developed the project in the 60th of the last century. The aim of the research is to find the relationship and effects of Bauhaus school in Cyprus through studying and analyzing some of Ahmet vural works. The methodology will depend on a comparison with the traditional housing that preceded Mr. Vural work and how the Modernism changed the main features of the housing on the Island.

JOURNAL OF CONTEMPORARY URBAN AFFAIRS (2017) 1(2), 21-32.

https://doi.org/10.25034/ijcua.2017.3645
\end{abstract}

\section{Introduction}

Modern architecture developed more than a century ago to find solutions suitable to solve the new concerns of the industrial revolution that changed the social idea of the world in all aspects. Architecture experienced crucial shifts in that era; there were new attitudes in Architecture and Urban Planning, and although the movement made breaks with the past and sometimes denied the whole tradition it also allowed the fundamental principles of architecture in new ways. The movement came

\footnotetext{
*Corresponding Author:

Department of Architecture, Cihan University, Iraq

E-mail address: mustafaamen@gmail.com
} 
with too many features and structures that societies were not familiar with, the new architecture carried many concepts from the industrial revolution most of them stood on the notion of the machine, new Technology, and science.

Some of the Modernism characteristics and structures becomes so internationally widespread that it works as signs of the movement everywhere in the world.

One of the main institutions that established the Modern movement in Europe was the Bauhaus school which established by Walter Gropius in 1919. Bauhaus adopted too many principles and ideas that were totally new to the architecture concept and theory at that time; their principles started from Simplicity, Angularity, Abstraction, Consistency, Unity, Organization, Economy, Subtlety, Continuity, Regularity, and Sharpness. Those because the" physical public space is a result of struggles between different ideologies, discourses, political decisions and daily activities taking place at personal, interpersonal, local, national, supranational and global scales" (Sadri, 2017). Those principles affected the architectural world and found its way through many applications in different parts of the world. So it becomes difficult to think about the modern movement without taking into account those principles and social forces that formalized those principles. The unlimited space or the international space that had a significant influence on the architecture space and form as well as the introduction of the new material, the anti- decorating, and Platonic forms had worked to reconstruct the architecture in the world. Cyprus as an Island close to the sources of the movement got the influence from the modern movement; the Modern Architecture propagated all over the Island with its neat, clean and functional forms.

The paper will study the effect of the Bauhaus modernism principles on changing the housing layout and architecture in the Island and how the modern movement changed the traditional way of building on the Island with a particular concentration on Nicosia. The study will concentrate on Efruz Housing which designed by Ahmet Vural, who developed the project in the 60th of the last century. There will be a comparison with the traditional housing that preceded Mr. Vural work and how the Modernism changed the main features of the housing on the Island.

\section{The Historical View}

In this section, there will be a brief discussion about the advent of the modern movement in Art and Architecture. Too many factors and worked together to formulate new ideas and expression in different fields of science and architecture. Within this century, the concept that the Greek culture has high values and should emulate in all life possibilities (Ballantyne, 2004). The very point for Modernism is that "the nature of what constituted beauty and the beautiful was undergoing revision, as was the idea of utility. The connection of beauty to a moral and ethical dimension was passing into a new phase, in which beauty identified, neutrally, with sensation and experience. Thus, beauty was no longer a moral entity or the embodiment of a higher truth; it associated with individual taste and individual striving (Karl, 1985, p. 117). There were a new taste and attitude that needed new approaches and manipulation translated and interpolated in the modern movement in art and architecture.

\subsection{Modernity and Modern Architecture}

The concept of Modernity conveyed in the eighteenth (Heynen, 1999) or the mid of the eighteen centuries by the Philosophers of the Enlightenment in their efforts and seventeenth century (Mallgrave, 2005, p. XV) as an attempt to develop Objective science, universal morality and law, and free art according to their inner logic. The words theory and modern both first came to prominence in the late seventeenth century. The analyst of architectural modernism must consider the relationship of architecture and architects to three key epistemological positions: history, theology, and politics (Hvattum \& Hermansen, 2004, p. 44). The main goals for 
the Enlightenment philosophers were stayed to the point "to utilize this accumulation of specific culture for the enrichment of everyday life that is to say, for the rational organization of everyday social life" (Heynen, 1999, p. 11). The most significant effects happened after the industrial revolutions and especially after the second industrial revolution with the beginning in the nineteenth century (Benevolo, 1977). As a result, the architectural world adopted new methods and claimed new methodology for their final outputs, Technical, material innovation and Functions of the buildings and compatibility with the environment was one of their goals. Therefore, Architecture is not a spectacle but a service security fitness and convenience.

\subsection{The Second Industrial Revolution 1856}

The Industrial Revolution, which started in England in the middle of the eighteenth century and extent across the globe by the beginning of World War II, shaped a new world (Outman \& Outman, 2003, p. IX). Moreover, give rise to building factories and new industry. The industrial revolution had a marvelous influence on nineteenth century Society "Productive efficiency, immigration from the country to the city was explosive, and living conditions in industrial cities were worse than at any other time in history" (Hvattum \& Hermansen, 2004, p. 224). Cities were faced new technology, and there were intentions toward quantifications and reliable standardizations (Ballantyne, 2004). Changes in patterns of movement with the expansion of inexpensive mass transport in made possible the growth of cities to sizes which was not possible before (Hvattum \& Hermansen, 2004). It was the advent of the mass community (Pevsner, 1968)or the machine age that demanded a response from art and architecture (Ballantyne, 2004). As a result, "Architecture and design for the masses must be functional, in the sense that they must be acceptable to all and that their well- functioning is the primary necessity" (Pevsner, 1968, p. 9). The new technology and materials increased the sense of Modern and Modernism which "flourished in the nineteenth century, especially in England, when the 1851 Exhibition in the Crystal Palace was the epitome of technological genius" (Karl, 1985, p. 9). The other invention in this era was the spread of Bessemer process 1 in the iron industry which led to replacing the cast Iron with steel the iron in all-purpose (Pevsner, 1968). The result was in Crystal Palace (Figure1). Later, in France there were the "triumphs of iron architecture at the exhibition of 1889 had still been the triumphs of engineers, even if the Eiffel Tower (Figure 2). By Its very height and Position became at once one of the chief constituents of the architectural scene of Paris.

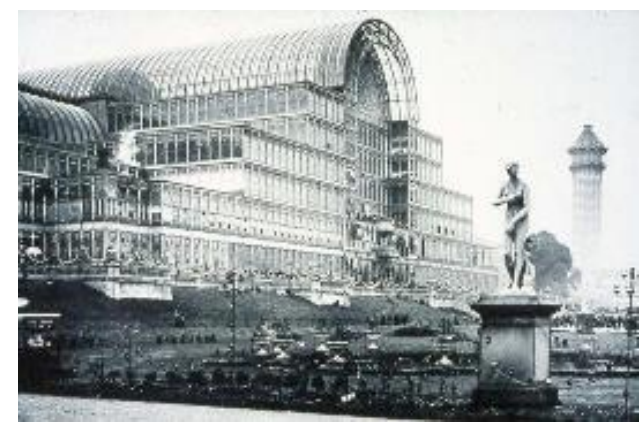

Figure 1. Crystal Palace (Pevsner, 1968).

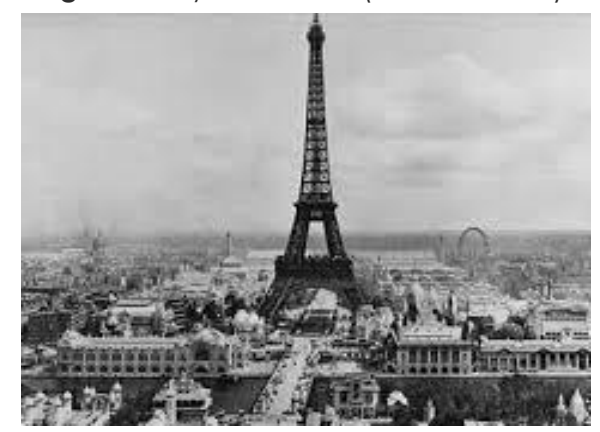

Figure 2. Eiffel Tower (Britannica, 2016).

\section{The emergence of Modern Movement.}

In the late nineteenth and early twentieth centuries, Europe was replete with many schools and direction in "Art and Architecture Cubism, Futurism, Expressionism, Constructivism, and De Stijl was fired by the belief that the Creative techniques of the past had to be overturned" (Ballantyne, 2004, p. 34). The Modern Movement 
insisted upon the strictness of the Machine Aesthetic. Also, insisted on the vision that was of the universal design solutions, universal standards of living, and universal aesthetic (Ballantyne, 2004). Historians such as Siegfried Giedion and Nicolaus Pevsner came to this conclusion that Modern architecture was the outcome of Mass Production, World View (weltanschauung) associated with industrial technology, Methodological bias in making history, focus on form and Material and Pay lip service to process that generates them. (Lefaivre \& Tzonis, 2004). The Modern movement "explained against a background of social, economic, technological, and artistic changes, and these must be duly acknowledged" (Ballantyne, 2004, p. 34). In the first quarter of the twentieth-century schools established and started to work in Europe, those schools and establishments shared similar principles united under the Modern Movement, Bauhaus in Germany and Le Corbusier in France, While De Stijl was working on similar principles in Netherlands. Later, on 1928, CIAM Congrès internationaux d'architecture modern worked to spread the modern Movement principles through working on landscape, urbanism, and industrial design. "The second C.I.A.M conference, held in Frankfurt in October 1929, was hosted by May and focused exclusively on the issue of housing" (Mallgrave, 2005). The era formed a "highly provocative standards and suggested the acceptable minimal housing square demands" ( Lejeune \& Sabatino, 2010, p. 69). New attitudes toward standardization in housing and uses the module in the design to achieve and provide the units to most of the people all around the globe. Housing advocates argued that low-cost construction would best be served by the normalization and the standardization of the existing production to conserve the traditional systems of production.

\section{Characteristics of Modern Movement:}

1. The absence of the ornament (Figure 3) (Ballantyne, 2004).
2. The Aesthetic Values based on creating simple, straight Shapes and forms, the whole Compositions stand on square forms, (Figure 4 ) (Pevsner, 1968).

3. Continuity of the space in all direction (Benevolo, 1977) .

4. Modern materials interpreted as steel and glass as well as Concrete Columns in their design and flat white colors (Figure 5) (Benevolo, 1977).

5. Functional design, especially in the Housing fields (Figure, 6) (Pevsner, 1968).

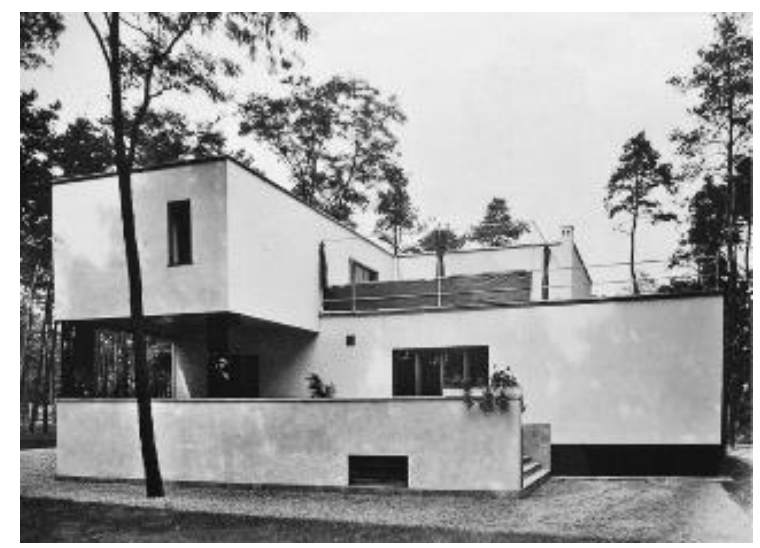

Figure 3. photograph, taken by Ise Gropius in 1926, became one of the most iconic images of the House Gropius after the building's destruction in 1945. (Pevsner, 1968).

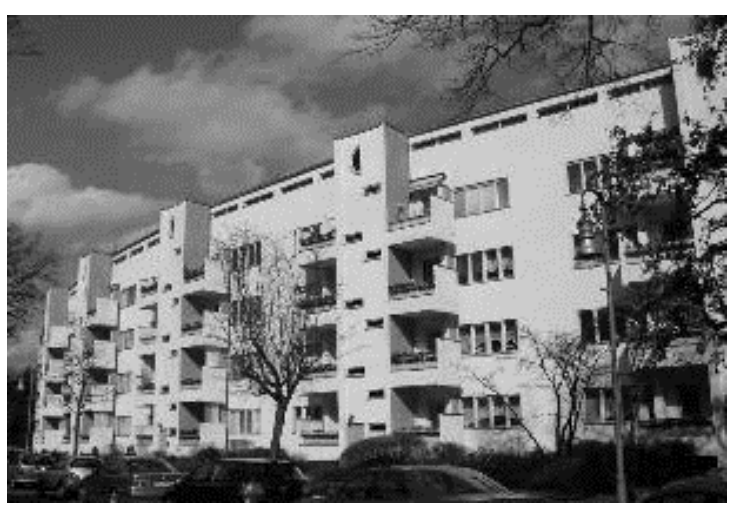

Figure 4. Großsiedlung Siemensstadt 1929 Gropius. (Pevsner, 1968). 


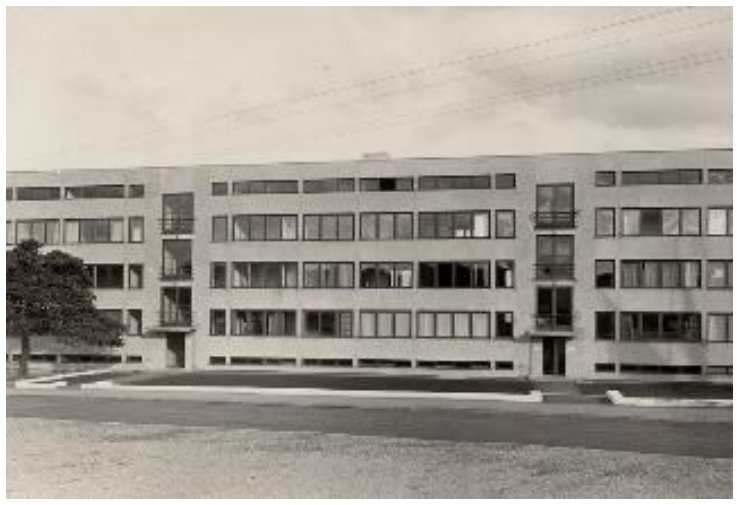

Figure 5. Ludwig Mies van der Rohe Weissenhof Housign Project. (Pevsner, 1968).

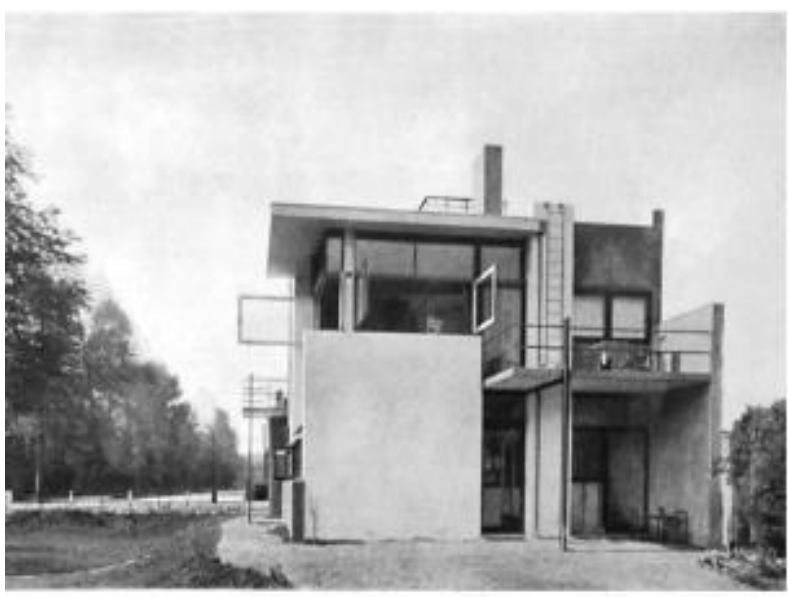

Figure 6. Garrit Rietveld, Schr"oder House, Utrecht, 19245. (Pevsner, 1968).

\section{Characteristics of Modern Housing Architecture.}

1. Prefabrication, there was a belief during the nineteenth century in prefabrication where the manufacture of buildings in basic form in workshops for transport to and final assembly on a remote building site developed from modest beginnings into an industry of quite substantial proportions (Lane, 2007).

2. Mass production spirit which was applicable through the standardization of both the technical and aesthetic sense with an ongoing search for standard types. Le Corbusier was a supporter of this idea as he said (Lane, 2007).

3. Module or Prototypes for industrial production (Benevolo, 1977).

4. Continues Space or the multiple uses of completed plans (Benevolo, 1977).

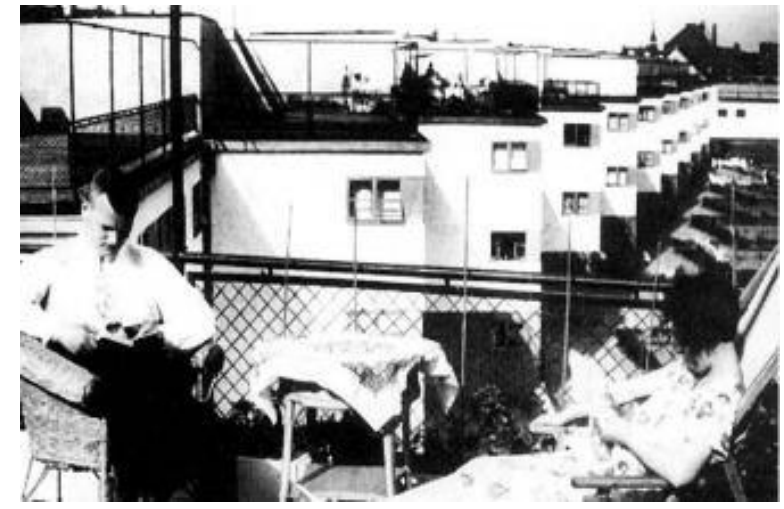

Figure 7 . Ernst May and staff, Bruchfeldstrasse Housing 1926. The utopian ideas implied in modernist housing can be seen even more clearly in Ernst May's Siedlungen in Frankfurt ,May's emphasis on the centrality of the community facility is clearly illustrated. (Lane, (2007).

\section{Bauhaus role in Architecture.}

The Bauhaus had a significant effect on formalizing the body of the Modern Movement, it is usually true to say that "The Modern Movement was embodied, aesthetically and pedagogically, when the Bauhaus moved to its new building and syllabus at Dessau in 1926. Within its irregular plan, glass curtain walls and steel and reinforced concrete frame beat an interdisciplinary heart so that all the departments furniture, theater, architecture, textiles, and so on - collaborated" (Ballantyne, 2004, p. 34). So in this section, we will review the main features and principles of the Bauhaus school.

\subsection{Establishment of Bauhaus in German}

Undoubtedly no other school in Germany was so closely connected to the cultural, political and socio-economic developments of the Weimer Republic as the Bauhaus. The Bauhaus established on the 1st April 1919 (Siebenbrodt \& Schobe, 2009). "Bauhaus based on the idea that the term Bauhaus (literally, construction house) invokes the metaphor of a medieval guild" (Mallgrave, 2005, p. 249).Bauhaus object was to "renovate art and architecture in line with other similar efforts, from which it drew numerous ideas for its work" (Siebenbrodt \& Schobe, 2009). Gropius saw the Bauhaus as a part of "reform ideas typical of the time and as a new kind of school, whose fundamental pedagogical 
concept based on reform ideas (Siebenbrodt \& Schobe, 2009). Bauhaus founder Walter Gropius affected by many people and schools in Germany like Ruskin, Olbrich, Behrens, (Darmstadt Artists' Colony) and others in Germany and The Dutch artists' group De Stijl which founded in 1917 with constructivist design principles that were propagated in Weimar by painter Theo van Doesburg. Walter Gropius repeatedly emphasized that the Bauhaus generate from the spirit of the Deutscher Werkbund. Founded by Hermann Muthesius (1861-1927) in Munich in 1907 as an association of artists, architects, businesspeople and experts.

\subsection{Bauhaus Workshops and Contributions}

Bauhaus composed of many workshops and departments that affected the different parts of art and architecture with its principles. It was possible to enter those workshops after the successful accomplishment of the preparatory course which was "necessary for acceptance into one of the Bauhaus workshops" (Siebenbrodt \& Schobe, 2009, p. 39). There were many workshops in the school to participate in the field that it related. The main workshops in Bauhaus were:

1. Pottery Workshop.

2. Stained Glass Painting Workshop.

3. Graphic Print Shop.

4. Typography/Printing and Advertising Workshop.

5. Mural Painting Workshop.

6. Stone Sculpting and Woodcarving/Plastic Workshop.

7. Weaving Workshop.

8. Carpentry/Furniture Workshop

9. Metal Workshop

10. Metal Workshop.

11. Architecture/Building Studies Building Department.

12. Photography/Photo Workshop.

\subsection{Bauhaus Philosophy and Principles}

1. Reunification of all artistic principles in the building, in combination with manual trades and workshop as educational fundamentals, were the focal point of its aims and objectives (Siebenbrodt \& Schobe, 2009) (Figure 8).

2. Deny the History and create a modern architecture without concern for location or history (Siebenbrodt \& Schobe, 2009).

3. Abstract shapes stand on square and rectangles that include all items used in the field of art in architecture (Siebenbrodt \& Schobe, 2009).

4. The module in Mass production, in housing and town planning (Pevsner, 1968) (Figure 9).

5. New Technology and Material, Especially the glass and Steel with Flat Concrete planes (Siebenbrodt \& Schobe, 2009).

6. White colors for the Architecture as the main colors (Craig, 1999).

7. Open plan and Flowing Space in the plan (Craig, 1999).

8. Standardization of the Elements used in the architecture and furniture Design. These were of standard design, but with modifications from year to year, and were constructed of reinforced concrete and cinder blocks (Figure 10) (Lane, 2007, p. 243).

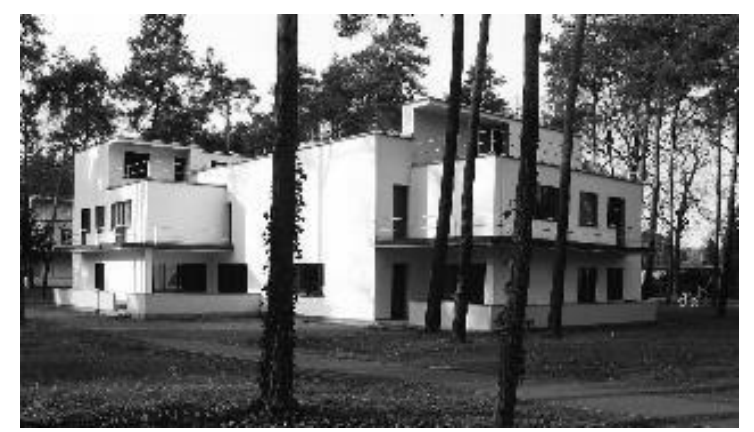

Figure 8. Walter Gropius, Masters' houses in Dessau, 1925/26, condition in 2005. 


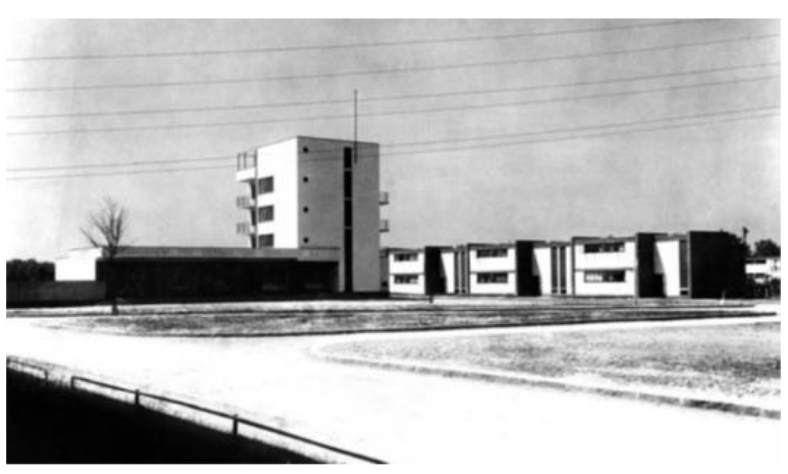

Figure 9. Walter Gropius and the Bauhaus, massproduced houses at Siedlung Törten-Dessau.

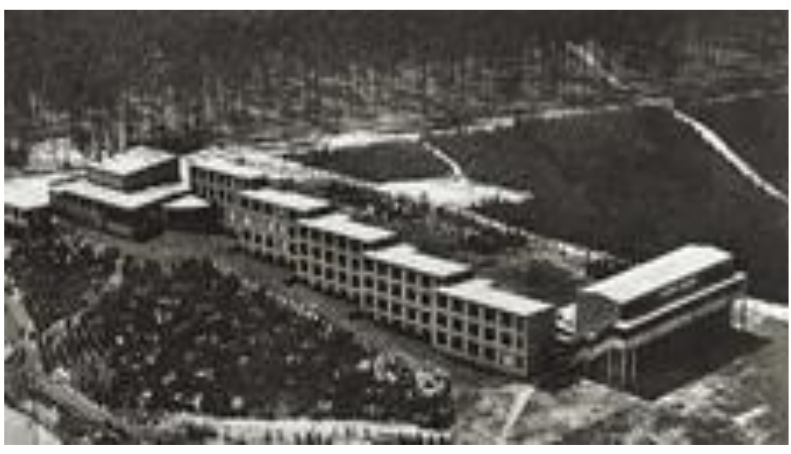

Figure 10. Hannes Meyer, Syndicate school of the ADGB in Bernau, aerial view by Junkers, 1928-30.

\section{The Case Study}

In this section we will focus on modern movement effects on the North Cyprus and in particular on the Nicosia city, as a case study, we selected the Efruz Mass Houses or Müdüroğlu designed by Ahmet Vural Behaeddin in between the $60^{\text {th }}$ and $70^{\text {th }}$ of the last Century.

\subsection{History of "the Case Study}

Efruz House,(Figure 11), "constructed in 1970 at Kumsal Quarter in Nicosia by Ahmet Vural Behaeddin, who was well known Turkish Cypriot architect in the island" (Esentepe, 2013, p. 76). Efruz project designed for "high-income households who has high-quality life standards" (Esentepe, 2013, p. 76). The whole project of a housing composed of are two-story row houses with three diverse design organization, the project designed on $10000 \mathrm{~m}^{2}$ ( 1 Hectare) $)^{2}$, with 34 units, the units area varies between $250 \mathrm{~m}^{2}$ to $300 \mathrm{~m}^{2}$.

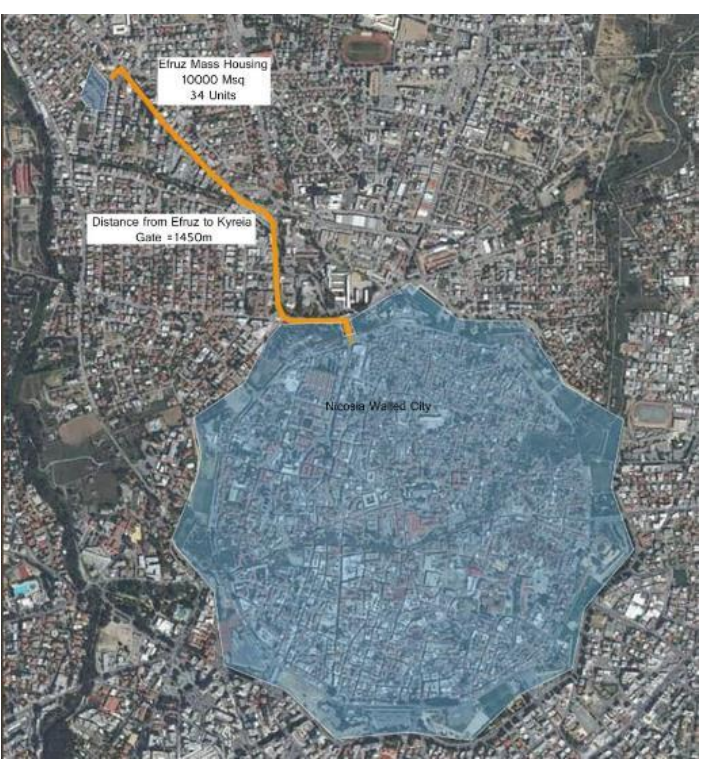

Figure 11. Efruz Massing housing in Nicosia Source (Image by Author from CartoDB GIS system)

\subsection{Analysis of the Projects.}

The Efruz housing impression indicate that the modernism imprint and the Bauhaus principles adopted by the architect with the urban and the stand alone units. The project

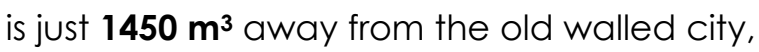
Ahmet Vural adopted straight and sharp line in his design to reflect the soul and insert the impression of the modern age, the straight space stand on the modernism philosophy of space as it was the main element that combined all the units around it in a direct way. Most of the units directed to the north (Figure 12), so it will be possible to open a large enough terrace to the south (Figure 13). The terraces are an enormous function in the daily life of the Cypriote people as they normally gather there to spend their evening. Some units oriented to the east therefore those units dealt with in a different way. The designer used some other manipulation like a natural stone for the east and closed the west elevation keeping some small windows or shutters for ventilation. 


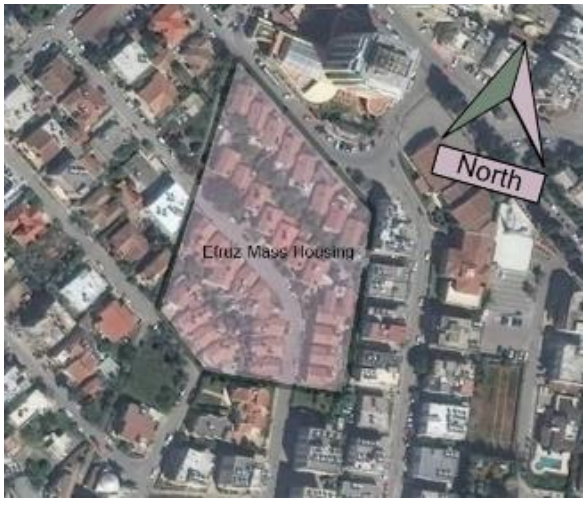

Figure 12. Efruz Mass House, Orientation toward North (Image by Author from CartoDB GIS system).

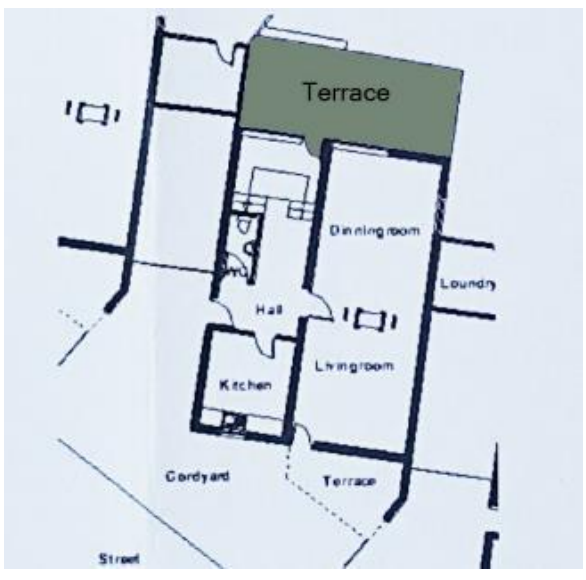

Figure 13. Terraces of Efruz Houses oriented to the south (Esentepe, 2013).

\subsection{Analysis of the Bauhaus Principles in the Project}

\subsubsection{Space}

Ahmet Vural used the continuous space in the internal design of Efruz units; there is a reflection of the (Open Plan) adopted from Bauhaus principles in the design, in his design for Efruz mass House he adopted three house types. All types shared a common characteristic which was the open plan and connection between the living and dining from one side and the kitchen with the entrance from the other side. In the (Figure 14,15 and 16) we could see clearly the clear strategy plan between the different parts of the house. The compound of Efruz contains more than three different design that has a direct message for the open plan and the continuous space. In Macit Ferdi house 1961 (Figure 17), Bahhadin adopted the same philosophy for the open space and accepted the same principle although the project was private and the site was accessible from all sides. Apparently, there is a sharp insistence on combining some space together then connect the group of the spaces by third space so that kind of mixing will achieve the maximum flexibility.

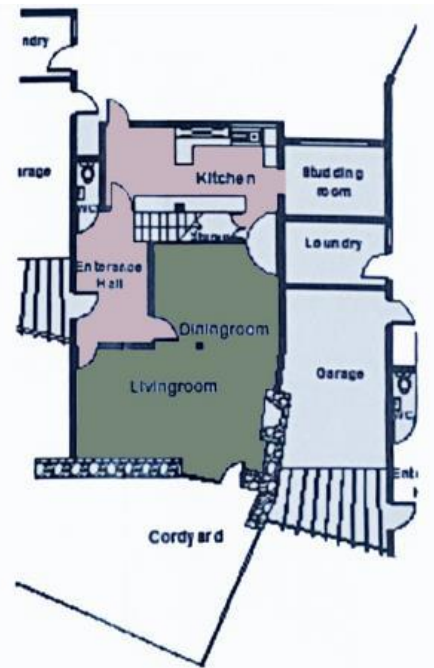

Figure 14. Efruz House Type 1 Open Plan (Esentepe, 2013).

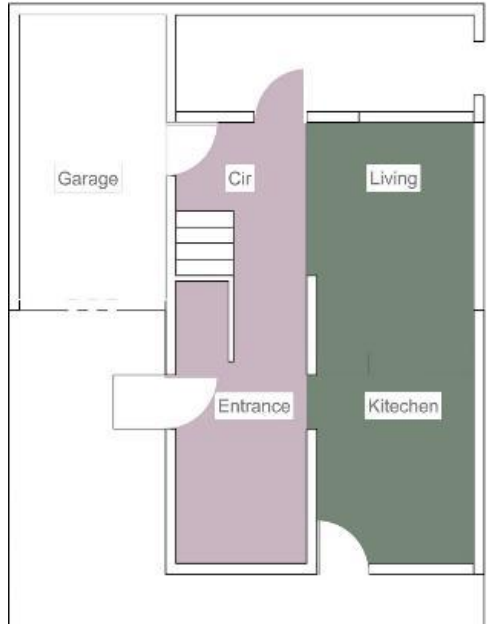

Figure 15. Efruz House Type 2, Open Plan (Drawing by Author). 


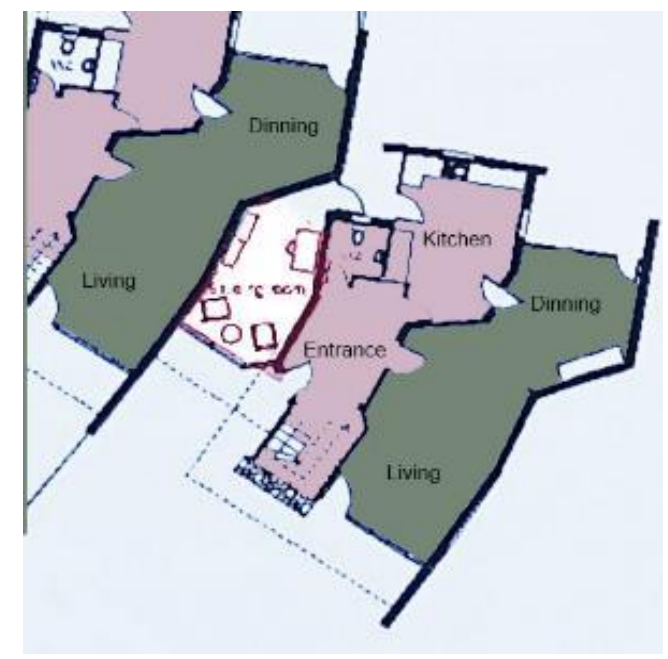

Figure 16. Efruz House Type3, Open Plan (Esentepe, 2013).

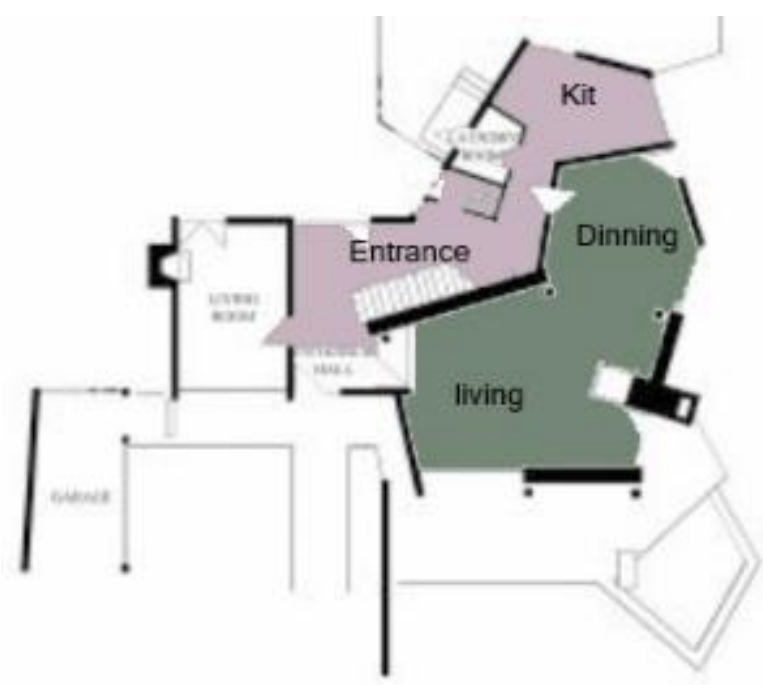

Figure 17. Macit Ferdi House, Open Plan (D.Celik, without date).

\subsubsection{Form}

Although Efruz house built in an area that is very close to the old city of Nicosia, which is rich in a unique history and full of architecture (Figure 18) . Efruz house, designed according to the Modernism philosophy of denying the history and adopted Bauhaus philosophy in using simple square shapes to compose and generate the final form. The design is clean from ornament and decoration in all its features. Square used for creating the ornament parts in the project as it appears in the (Figure 19)

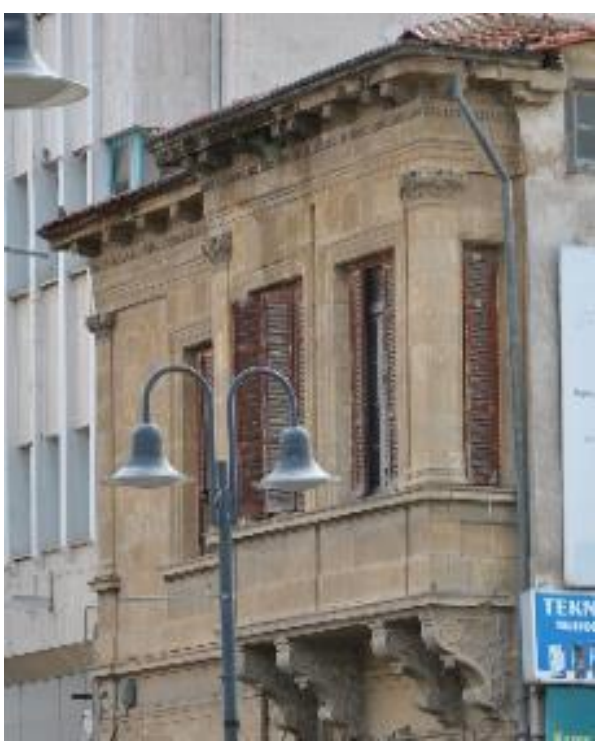

Figure 18. Decoration in Walled City of Nicosia (Image by Author, 2016).

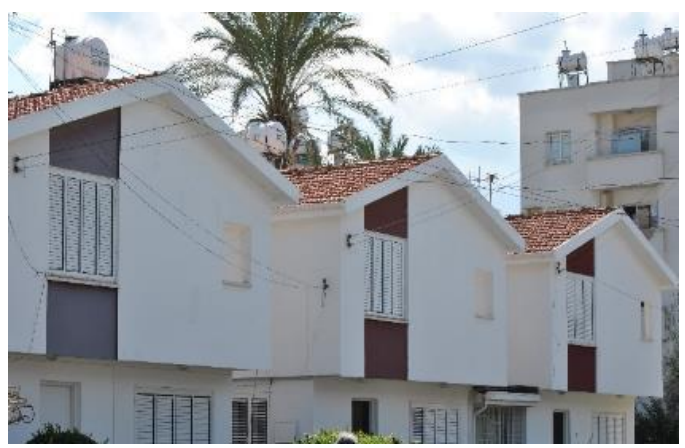

Figure 19. The Clean, abstract and White surfaces for Efruz Housing (Image by Author, 2016).

\subsubsection{Orientation}

Ahmet Vural affected by Walter Gropius work of mass-produced houses at Siedlung Törten-Dessau where all the units created with the same module and oriented to the south by Gropius to create the maximum functionality and how to get the best from the sunlight. In Efruz, Ahmet Vural went one step more when he decided to design each elevation in a different way to reflect the direction of the oriented elevation. All the units oriented toward the north, but the architect created balconies and open area in the south orientation so the family could spend their time in that part of the house and enjoy their time in the winter while avoiding the direct sunlight in summer. The 
manipulation of the elevation is very clear in the (Figure 20, 21, 22 and 23), where Vural designed each elevation according to the sun direction, terraces to the west and the open windows to the east while he almost close the west elevations with white plastered walls.

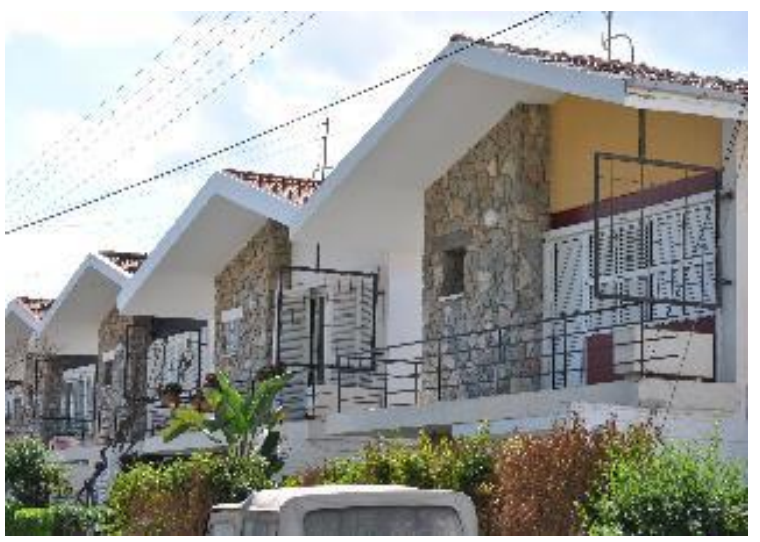

Figure 20. North Elevation of Efrus House (Image by Author, 2016)

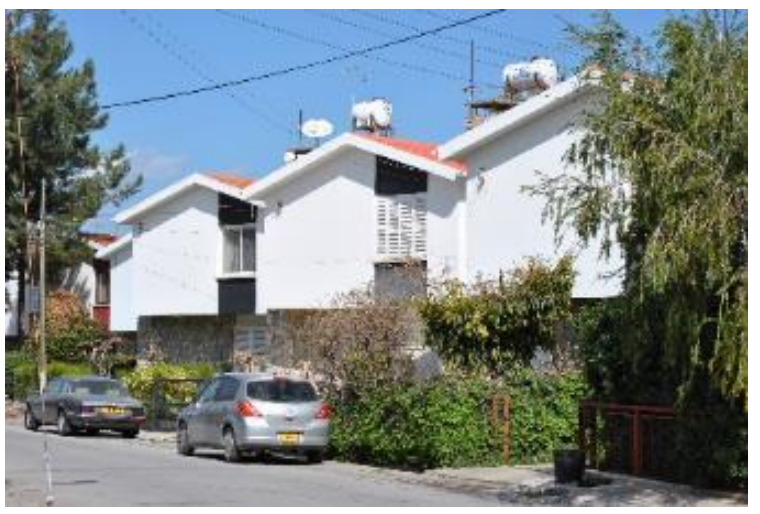

Figure 21. West Elevation of Efrus House (Image by Author, 2016).

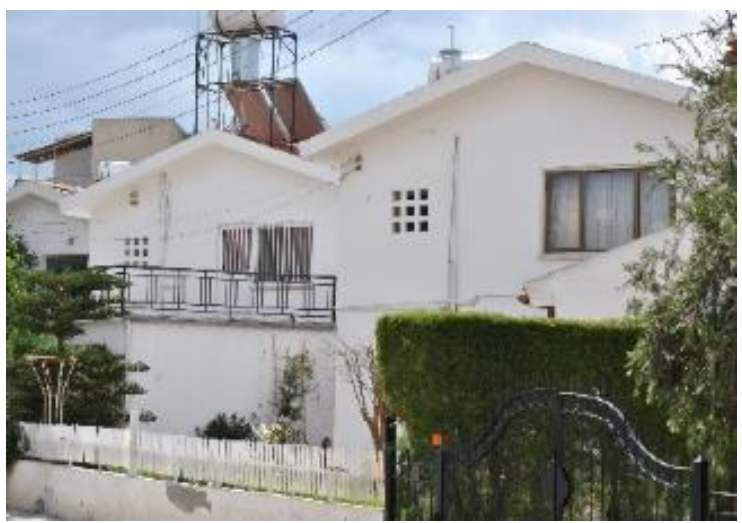

Figure 22. East Elevation of Efrus House (Image by Author, 2016).

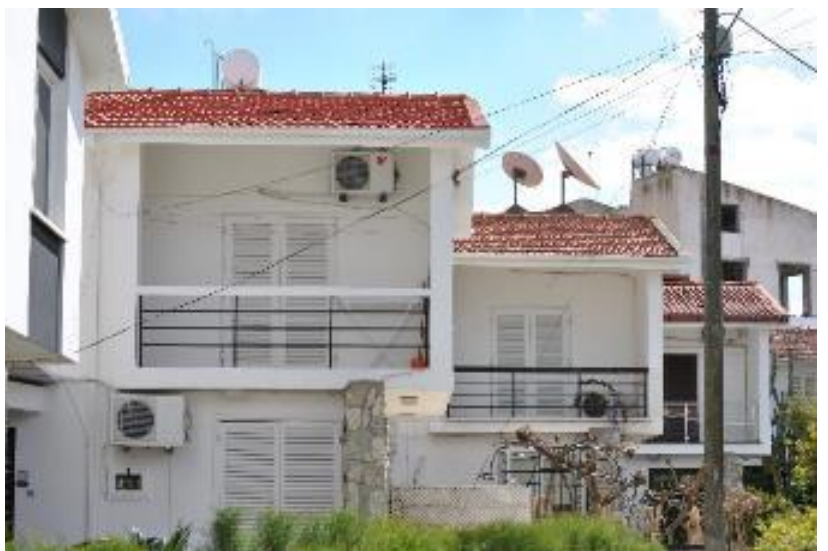

Figure 23. South Elevation Efrus House (Image by Author, 2016).

\subsubsection{Colors and Materials}

The Bauhaus principles is evident in Ahmet Vural work. the whole project colored in the white colors (Bauhaus style) and used the concrete as the main structure for the mass units as a reflection of the modernism in the project. there were some local materials utilized by the architect in the elevation (Figure 24) and (Figure $25)$, also he used the brick tiles on the pitched roof. The same principles had adopted by Ahmet Vural in 1961 when he designed Macit house in Nicosia (Figure 26) and (Figure (27).

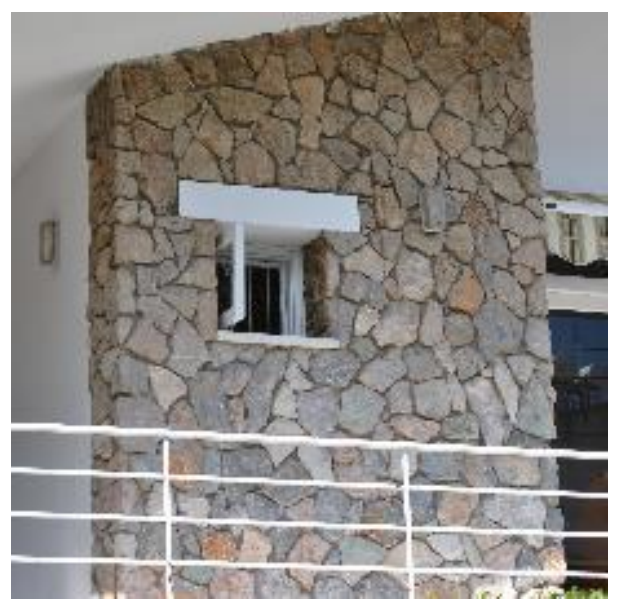

Figure 24. Details of Efrus House (Image by Author, 2016) 


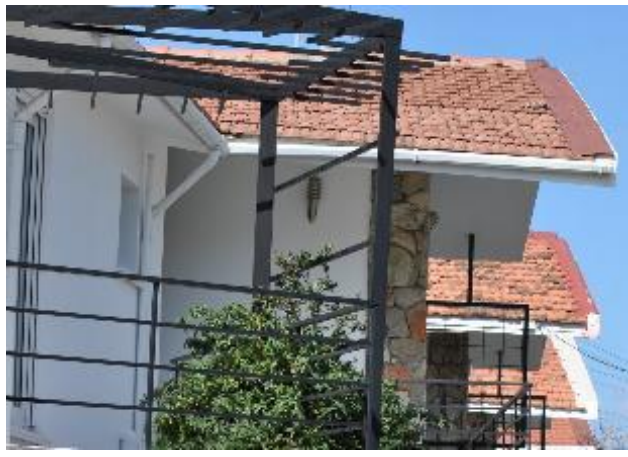

Figure 25. Efrus House (Image by Author, 2016)

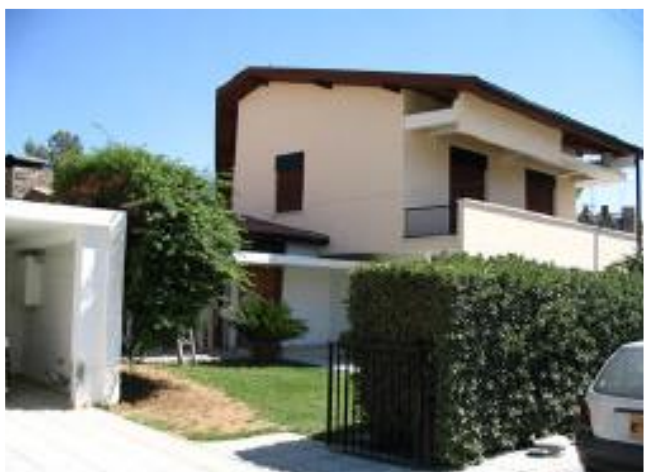

Figure 26. Ferdi Macit House MACIT FERDI HOUSE, NICOSIA 1961 ( D.Celik, without date).

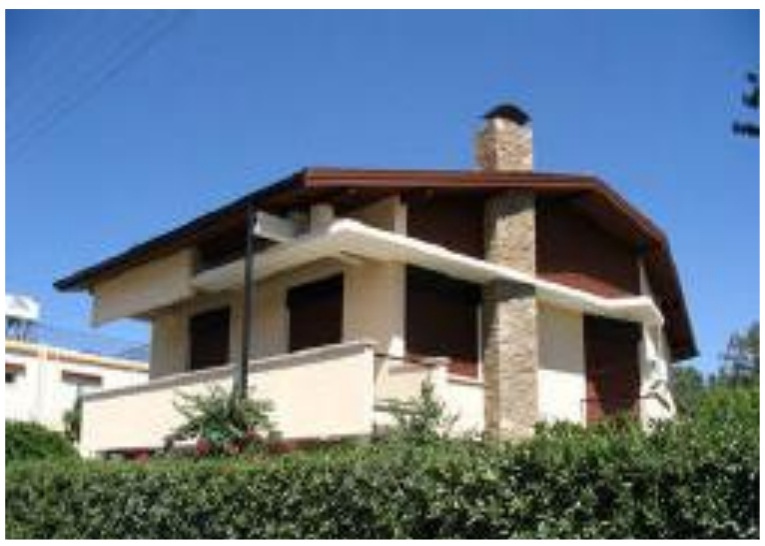

Figure 27. Ferdi Macit House MACIT FERDI HOUSE, NICOSIA 1961 (D.Celik, without date).

\subsubsection{Module, Prefabrication and}

\section{Standardization}

There are four types of the housing in the project, the reason behind that stand on the idea that the project has designed for the wealthy or hi income people and not for the low income as the philosophy adopted by Bauhaus school. same reason prevented the use of the prefabrication in the project, all this lead to the idea that the project was not with the main compatibility with the Bauhaus principles within this point.

\section{Conclusion}

There is the influence of Bauhaus principles in the Ahmet Vural work in Efruz housing; some principles were totally adopted and followed the open plan policy and orientation with function while some like Module and standardization were not accepted because of other local effects and factors. Although Cyprus is replete with rich heritage with the prominence of the old walled city of Nicosia, Ahmet Vural denied the whole history of the town in his designs keeping white abstract wall instead of the wealthy and dynamic influence of the old town. Vural type stand on creating two group of spaces then connect those group with third space as it is shown in the (Figure 26).

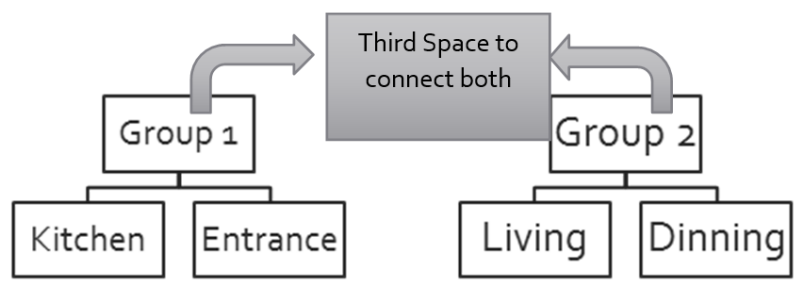

Figure 28. Ahmet Vural prototype that existed in Efruz housing and Macit Ferdi house. (Developed by Author).

The result from Table (1) shows that Ahmet Vural accepted the different principles of the Modernism as it cited by Bauhaus except the Module and standardization which might behave count achieved according to some social reason.

Table 1. Comparison between Bauahus and Ahmet Vural work (Developed by Author).

\begin{tabular}{|l|l|l|}
\hline BAUHAUS PRINCIPLES & EFRUZ HOUSING & MACIT FERDI HOUSE \\
\hline OPEN PLAN & 1 & 1 \\
\hline FORM & 1 & 1 \\
\hline COLORS \& MATERIALS & 1 & 1 \\
\hline MODULE AND PREFAB. & 0 & 0 \\
\hline TOTAL & 3 & 3 \\
\hline
\end{tabular}

\section{Acknowledgments}

This research did not receive any specific grant from funding agencies in the public, commercial, or non-for-profit sectors. 


\section{References}

Lejeune, J. F., \& Sabatino, M. (2010). Modern Architecture and the Mediterranean. Routledge: Routledge.

Ballantyne, A. (2004). Architectures Modernism and After. Oxford: Blackwell Publishing.

Benevolo, L. (1977). History of modern architecture. Massachusetts: MIT press.

Britanica, E. (2016, 422 ). Bessemer process. Retrieved from Encyclopedia Britanica: http://global.britannica.com/technology/ Bessemer-process

Craig, M. K. (1999). The Bauhaus and America: First Contacts, 1919-36. MIT Press.

D. Celik, Z. E. (without date). ANALYSIS OF THE MODERNIST LANGUAGE IN CYPRUS: A CASE STUDY ON A LOCAL ARCHITECT. Famagusta: Eastern Mediterranean University.

Esentepe, B. M. (2013). Space Transformation and Change in Mass Housing In Nicosia, North Cyprus. Gazimağusa, North Cyprus: Eastern Mediterranean University.

Heynen, H. (1999). Architecture and Modernity. Cambrdige: MIT Press.

Hvattum, M., \& Hermansen, C. (2004). Tracing Modernity: Manifestations of the modern in architecture and the city. London: Rutledge.

James L Outman \& Elisabeth M Outman. (2003). Industrial Revolution: the Primary Source. Thomson.

Jeffrey Saletnik \& Robin Schuldenfrei . (2009). Bauhaus Construct. New York: Routledge.

Karl, F. R. (1985). Modern And Modernism: The Sovereignty of the Artist 1885-1925. New York: Athenum.

Lane, B. M. (2007). Housing and Dwelling: Perspectives on Modern Domestic Architecture. London: Rutledge.

Lefaivre, L., \& Tzonis, A. (2004). The Emergence of Modern Architecture. London: Routledge.
Mallgrave, H. F. (2005). Modern Architectural theory : A Historical Survey, 1673-1968. Cambridge University Press.

Mari Hvattum and Christian Hermansen. (2004). Tracing Modernity: Manifestations of the modern in architecture and the city. Rutledge.

Outman, E. M., \& Outman, J. L. (2003). Industrial Revolurion Primary Source. London: Thomson Gale.

Pevsner, N. (1968). The Sources Of Modern Architecture And Design. FREDERICK A.PRAEGER.

Sadri, S. Z. (2017). The Scale of Public Space: Taksim Square in Istanbul. Journal of Contemporary Urban Affairs, 67-75.

Siebenbrodt, M. (2009). Bauhaus: A Conceptual Model . Berlin: Hatje Cantz.

Siebenbrodt, M., \& Schobe, L. (2009). Bahaus 1919-1933. New York: Parkston International. 